\title{
Economic and Social Implications and Challenges of Relocation of Street Vendors in a Highly Urbanized City
}

\author{
Joselito T. Bayatan ${ }^{1}$ and Anabelle S. Palic ${ }^{2}$ \\ 1,2University of Negros Occidental-Recoletos, Bacolod City, Philippines
}

\section{Article history:}

Revised: 14 December 2020

Accepted: 31 December 2020

\section{Keywords:}

Public administration

Socio-economic implications

Relocation

Street vendors

Descriptive-comparative

Highly urbanized city

Philippines
Submitted: 3 November 2020

ABSTRACT. On July 29, 2019, the Department of the Interior and Local Government (DILG) issued Memorandum Circular 2019-121 (DILG MC 2019-121), ordering the local chief executives to clear roads, sidewalks, and rights-of-way of obstructions. The descriptive-comparative research design was used to describe the economic and social implications of their relocation. A validated and reliability-tested survey questionnaire was used to gather data from 197 displaced vendors peddling in the downtown of a highly urbanized city. The findings of the study showed that the relocation of the displaced vendors did not change their economic conditions in terms of their average monthly sales, expenses, and income, but significantly differ when grouped and compared according to their age, educational attainment, family size, years of vending, and types of merchandise. Likewise, their social wellbeing did not change in terms of education and health and significantly differ when grouped and compared according to the aforementioned variables. Moreover, the major challenges faced by the relocated vendors were as follows: their means of livelihood is very difficult; not enough financial support is given during their relocation; limited space/trading site; and lack of access to the credit facility. The local government may utilize the study to implement a transit-oriented development of these vendors.

\subsection{Introduction}

Street vending is an informal sector activity that is a major source of employment and income for urban residents, especially in developing countries (Forkuor et al., 2017). Although it is considered an easy work, it is a universal phenomenon (Indira, 2014) that is described by Graaff and Ha (2015, p.2) as a "global and urban practice found in both the northern and the southern hemispheres."

The regulations and deregulations about the street vendors usually involve relocation, which occurs in the Philippines and other parts of the globe, including Asia. In Central Java Province, Indonesia, the increasing number of street vendors brought many complaints to the local government. Street vendors lack operational needs; hence, they may cause health risks, traffic problems, and illegal sidewalk occupations. However, they can raise issues against the government about the lack of holistic and sustainable government programs (Recio \& Gomez, 2013).

The unregulated street vendors occupied the public space indiscriminately, resulting in difficulty in traffic flows, the degrading scenic quality of the city, and environmental pollution. However, in a study conducted, which resulted in the formulation and implementation of the Street Vendor Management Plan, vendors gained markets and increased their profits compared to what they could have made in previous locations. The relocation program generated new economic activities, parking operators, market operation, and management, among others (Gervasi, 2010).

Then on July 31, 2019, pursuant to DILG MC 2019-121, the City Mayor of a highly urbanized city subsequently issued Memorandum Circular No. 87 (MC No. 87), primarily directing all the local Punong Barangays and Barangay Officials to implement the order mandated in the said memo. Subsequently, another Memorandum Order No. 110 dated September 11, 2019 (MC No. 110) was issued emphasizing the consequences of a penalty covered in Sec. 60 (c) of the R.A. 7160 . Thus, the immediate necessity to clear the sidewalks and public alleys of vendors and their consequential relocation are inevitable.

This study determined the social and economic implications and challenges of the relocation of sidewalk vendors engaged in different kinds of trade in compliance with the existing laws. The findings served as the basis for the formulation of the Proposed Comprehensive Relocation Program.

\subsection{Framework of the Study}

This study is anchored on the "Structuralist Perspective Theory," a concept of street entrepreneurship as a survival practice conducted out of economic necessity. It is being espoused in the modern era by scholars in the informal economy affecting poverty, such as Bhowmik (2003; 
2005). By adopting this theory, the government may be better positioned to seriously recognize the alternative needs of the street vendors and provide them with improved conditions in their livelihood, as the grant of affordable capital and establishing alternative locations in a regulated environment.

Another theory, the Dixon - Critical Theory, critiques perceived objective realities and focuses on transformation and emancipation. Its main goal is to strive for perfection as a means for improvement (Dixon, 2017). This theory allows public acceptability of the street vending phenomenon. When vendors are provided with an environment to be in the "right place at the right time," the public may adapt to the fact that street vendors are key players in providing consumers' ordinary needs in a very informal manner.

Lastly, the "Soft State" theory is a precept introduced by Gunmar Myrdal (1974), a Nobel Prize economist and sociologist. He believed that when a state adopts a lenient attitude towards social deviance, then a state would certainly weaken its capacity to enforce the law. This theory necessarily calls for strong implementation in the regulation of street vendors for their relocation. Once street vendors move to their proper relocation site under conducive conditions, the state will no longer extend tolerance on their return to the streets and open areas illegally occupied by them without the pain of legal sanctions.

This study obtained baseline data regarding the role of the street vendors' demographic profile. The extent of the economic implications was determined based on the street vendors' sales, expenses, income. In contrast, social implications were measured in terms of their education and health. Likewise, the challenges encountered by vendors were explored, and the proposed Comprehensive Relocation Program was formulated based on the findings of the study.

\subsection{Methods}

The study used the quantitative research approach utilizing the descriptive-comparative design. The design was employed to assess the extent of economic implications of relocated street vendors in terms of their average monthly sales, expenses, and income as assessed by the vendors themselves, when taken as a whole and when grouped according to age, sex, educational attainment, family size, years of vending, and types of merchandise, as well as the extent of the social implications of relocation in the areas of education and health. Finally, this study investigated the challenges encountered by the vendors.

A researcher-made survey questionnaire was used to gather the data on the respondents' profile and the extent of economic and social implications of their relocation using a five-point Likerttype statement. Moreover, a checklist is provided for the respondents to identify the challenges and problems encountered in the relocation process.

Descriptive and comparative analyses utilizing the mean and standard deviation were employed to determine the extent of economic and social implications among street vendors when grouped according to the aforementioned variables. Likewise, frequency count and percentage were used to analyze the data on the challenges encountered by the vendors.

Meanwhile, an independent sample t-test was used to determine the significant difference in the extent of economic and social implications involving the variables age, sex, family size, and years of vending. Simultaneously, the One-way Analysis of Variance (ANOVA) and Tukey's post hoc test were employed on the variables educational attainment and types of merchandise sold.

\subsection{Results and Discussion}

\section{Profile of the street vendors}

Table 1 shows that the majority of the relocated vendors were more than 49 years of age $(p=$ $51.8 \%)$, a good number of them were high school graduates $(p=49.2 \%)$, had at most five dependent family members $(p=65.5 \%)$, had been vendors for more than 27 years $(p=51.3 \%)$, and had been selling dry goods $(p=51.8 \%)$.

The findings indicate that peddling on the sidewalks has been their social and economic practice of livelihood. Peddling established by past studies has been considered the informal economy of society (Graaff \& Ha, 2015; Forkuor et al., 2017; Taylor, 2017).

The age of 49 years old and their trading for the past 27 years may prove that vending along sidewalks has long been a social and economic phenomenon (Singh, 2017). Moreover, selling dry 
goods is the easiest and does not require so much intelligence or exceptional skills. They do not get spoiled that may endanger the vendors' capital (Dhungel \& Dhungel, 2011). Undeniably, this also suits the economic status of most of the vendors (Golosino, 2012).

Table 1. Profile of the street vendors

\begin{tabular}{llcc}
\hline & Variables & f & $\%$ \\
\hline \multirow{2}{*}{ Age } & Younger & 95 & 48.2 \\
& Older & 102 & 51.8 \\
Educational & Elementary & 55 & 27.9 \\
Attainment & High School & 97 & 49.2 \\
& College & 43 & 21.8 \\
Family Size & ALS/Voc & 2 & 1.0 \\
& Few & 129 & 65.5 \\
Years of Vending & Many & 68 & 34.5 \\
& Shorter & 96 & 48.7 \\
Vendor's Type of & Longer & 101 & 51.3 \\
Goods/Merchandise & Type A (Dry Goods) & 102 & 51.8 \\
& Type B (Groceries) & 28 & 14.2 \\
& Type C (Vegetables / Fruits) & 49 & 24.9 \\
& Type D (Food) & 18 & 9.1 \\
& & 197 & 100 \\
\hline & & &
\end{tabular}

Furthermore, the informal manner of livelihood may be best explained because most of the vendors had only reached secondary education (Kolm \& Larsen, 2016; Purnomo, 2017). Indonesian (Purnomo, 2017) and Bangladeshi (Khairuzzaman, Chowdhury, Zaman, Mamun, \& Bari, 2014) street vendors have a low level of education.

\section{Extent of economic implications of relocation of street vendors}

Table 2 shows that the extent of economic implications among vendors regarding their average monthly sales was low $(M=1.81, S D=1.049)$, indicating that relocation has a poor positive economic implication in terms of sales.

The low rating in terms of monthly sales shows that the relocation would have caused the loss of customers and affected their accessibility to the new relocation site. Taylor (2017) cited the case in Indonesia, where some of the relocated vendors complained of diminished income. On the other hand, Gervasi's (2010) study confirms how a government's relocation program can benefit street vendors due to the economic activities generated by such relocation program.

Likewise, the extent of economic implications among the relocated vendors regarding their average monthly expenses was low $(M=1.99, S D=1.062)$. These low ratings mean that the relocation has a poor positive economic implication regarding the average monthly expense.

What would have contributed to the increase in the expenses is the cost of handling their inventories and the additional cost of transporting the goods of the vendors away from the main public route of public utilities. This experience is similar to that of the relocated vendors in Purwokerto, Java, Indonesia (Purnomo, 2017).

The expenses on electricity, water utilities, and rentals are not much of a concern since the daily rate of the lease is between P20.00 and P75.00 as prescribed by City Ordinance No. 286 (otherwise known as the Ordinance Establishing Vendors' Plaza and Jeepney Terminal at the Reclamation Area). However, Purnomo (2017) found increases in the expenses, including labor, transportation, raw materials, electricity, rent, hygiene, garbage, and community fees after the relocation.

Moreover, the economic implications among vendors regarding their average monthly income were low $(\mathrm{M}=1.82, \mathrm{SD}=1.110)$. The low income is brought by about low monthly sales. If the sales 
problems may be duly addressed, the matter of increased income to meet their family needs may also be readily addressed (Purnomo, 2017).

Nonetheless, the extent of economic implications among vendors when grouped by age was "low" ( $M=2.03, S D=1.193)$ for the younger vendors and "very low" $(M=1.72, S D=0.961)$ for the older vendors. These findings mean that the relocation has poor economic implications for younger vendors and very poor economic implications for the older ones.

The younger vendors' "low" income compared to the older ones' "very low" earnings may be explained by the situation where the former return to the downtown area to peddle. In contrast, the old vendors prefer to remain in the Vendors' Plaza, perhaps due to physical constraints caused by health and age conditions. As such, peddling in the downtown area is a public nuisance that can result in punitive sanctions (Ghani, 2011; Panwar, 2015).

In contrast, in terms of their educational attainment, the economic implications were "low" for all groups except for the vocational and ALS graduates $(M=3.57, S D=1.838)$. They gave a "high" rating. These data reveal that the relocation had poor economic implications to vendors with elementary, high school, and college-level vendors but had a high extent of economic implications to ALS/Vocational Graduates (Kolm \& Larsen, 2016). Despite their condition, it could be gleaned that this group of vendors still manage to strive for advancement in education, demonstrating their resiliency (Khairuzzaman et al., 2014).

However, when grouped according to family size, economic implications were "low" for both groups, indicating a poor extent of economic implications. The group with few members $(M=1.82$, $S D=1.038)$ had a lower rating than the group with many members $(M=1.98, S D=1.137)$. These results imply that the vendors' negative economic condition is aggravated by the increased number of their family members. Depletion in income is directly proportional to the increase in the number of family dependents.

In terms of their number of years as vendors, those with shorter selling experience gave "low" ratings $(\mathrm{M}=1.99, \mathrm{SD}=1.129)$, indicating the poor extent of economic implications, while the vendors with longer selling experience gave "very low" ratings $(M=1.76, S D=1.009)$, indicating the very poor extent of economic implications. This shows that sidewalk peddling is a low-income generating business.

Finally, when grouped by the type of goods or merchandise, all group showed "low" extent of economic implications: Type $A(M=1.87, S D=0.992)$, Type $D(M=2.45, S D=1.415)$, and Type $B(M$ $=2.50, \mathrm{SD}=1.009)$ except for the group selling Type $\mathrm{C}$ that gave a "very low" rating $(\mathrm{M}=1.30, \mathrm{SD}=$ 0.789). As Walsh (2010) and Kumari (2016) explained, the relocation site's proper facilities' provisions attract the consumers to have something to do with this factor of low earnings. 
Table 2. Extent of economic implications of the relocation of the street vendors

\begin{tabular}{|c|c|c|c|c|c|c|c|c|c|c|c|c|}
\hline \multirow{2}{*}{ Variable } & \multicolumn{3}{|c|}{ Monthly Sales } & \multicolumn{3}{|c|}{ Monthly Expenses } & \multicolumn{3}{|c|}{ Monthly Income } & \multicolumn{3}{|c|}{ Average } \\
\hline & M & SD & Int & $\mathbf{M}$ & SD & Int & $\mathbf{M}$ & SD & Int & M & SD & Int \\
\hline \multicolumn{13}{|l|}{ Age } \\
\hline Younger & 1.99 & 1.17 & Lo & 2.18 & 1.12 & Lo & 1.93 & 1.29 & Lo & 2.03 & 1.19 & Lo \\
\hline Older & 1.63 & 0.89 & VL & 1.82 & 0.98 & $\mathrm{VL}$ & 1.71 & 1.01 & $V L$ & 1.72 & 0.96 & $V L$ \\
\hline \multicolumn{13}{|c|}{ Educational Attainment } \\
\hline Elementary & 1.82 & 1.11 & Lo & 2.02 & 1.02 & Lo & 1.87 & 1.19 & Lo & 1.90 & 1.11 & Lo \\
\hline High School & 1.77 & 1.00 & VL & 1.97 & 1.09 & Lo & 1.74 & 1.04 & $V L$ & 1.83 & 1.04 & Lo \\
\hline College & 1.78 & 1.09 & VL & 1.95 & 1.03 & Lo & 1.84 & 1.09 & Lo & 1.86 & 1.07 & Lo \\
\hline ALS/Voc & 3.9 & 1.56 & $\mathrm{Hi}$ & 3.20 & 1.98 & Mo & 3.60 & 1.98 & $\mathrm{Hi}$ & 3.57 & 1.84 & $\mathrm{Hi}$ \\
\hline \multicolumn{13}{|l|}{ Family Size } \\
\hline Few & 1.75 & 1.01 & VL & 1.96 & 1.06 & Lo & 1.74 & 1.04 & $V L$ & 1.82 & 1.04 & Lo \\
\hline Many & 1.91 & 1.12 & Lo & 2.06 & 1.07 & Lo & 1.96 & 1.22 & Lo & 1.98 & 1.14 & Lo \\
\hline \multicolumn{13}{|c|}{ Years of Vending } \\
\hline Shorter & 1.95 & 1.11 & Lo & 2.13 & 1.12 & Lo & 1.89 & 1.15 & Lo & 1.99 & 1.13 & Lo \\
\hline Longer & 1.67 & 0.97 & VL & 1.86 & 0.99 & Lo & 1.75 & 1.07 & VL & 1.76 & 1.01 & $V L$ \\
\hline \multicolumn{13}{|c|}{ Vendor's Type of Goods/Merchandise } \\
\hline Type A & 1.80 & 0.98 & VL & 2.08 & 1.02 & Lo & 1.73 & 0.98 & VL & 1.87 & 0.99 & Lo \\
\hline Type B & 2.34 & 1.04 & Lo & 2.52 & 0.89 & Lo & 2.63 & 1.10 & Lo & 2.50 & 1.01 & Lo \\
\hline Type C & 1.30 & 0.81 & VL & 1.28 & 0.69 & VL & 1.33 & 0.89 & $V L$ & 1.30 & 0.80 & $\mathrm{VL}$ \\
\hline Type D & 2.41 & 1.36 & Lo & 2.61 & 1.39 & Lo & 2.33 & 1.50 & Lo & 2.45 & 1.42 & Lo \\
\hline As a Whole & 1.81 & 1.05 & Lo & 1.99 & 1.06 & Lo & 1.82 & 1.11 & Lo & 1.87 & 1.07 & Lo \\
\hline
\end{tabular}

Note: $V L=$ Very Low, Lo=Low, Mo=Moderate, $\mathrm{Hi}=$ High

\section{Extent of social implications of relocation of the street vendors}

Table 3 reveals that the extent of social implications among the relocated vendors concerning their education was low $(M=1.91, S D=0.945)$. The result suggests that the relocation site has poor access to educational services.

The relocation site has no security and safety measures for the children, especially those in the schooling age (Kumari, 2016). Although the downtown area at which the vendors were originally situated appears to be considerably far from the public schools where most children of the vendors are enrolled, the new vendors' site cannot be comparably far from the same schools.

Likewise, the extent of social implications among vendors regarding their health was also low $(M=1.91, S D=0.945)$. The low rating indicates that the relocation has poor access to health services (Khairuzzaman et al., 2014).

Specifically, the social implications among vendors when grouped according to age was "low" for both groups, with the older giving a slightly higher rating $(\mathrm{M}=1.91, \mathrm{SD}=0.949)$ than the younger $(\mathrm{M}=1.89, \mathrm{SD}=0.956)$.

Such low ratings mean a poor extent of social implications or poor access to education and health services. Both registered low benefits to health and education. These health and education aspects may seem secondary for them since these could be an added financial burden (Purnomo, 2017).

In terms of their educational attainment, results revealed a "low" extent for all groups, meaning poor access to the services, except for the Vocational and ALS graduates with "moderate" ratings (M $=3.30, \mathrm{SD}=0.990$ ) or average access to the services. 
Vendors with a vocational course and ALS graduates can easily adapt to a hard life. This positive attitude may encourage the government to set up plans to help them cope with their economic condition while uplifting their health and education status (Khairuzzaman et al., 2014).

In terms of the number of dependent family members, few family members registered "low" extent $\mathrm{M}=1.95, \mathrm{SD}=0.981$ ) while "very low" was registered by vendors with many family members $(M=1.80, S D=0.904)$. These data reveal the poor access of the smaller family size to the social services and the very poor access among the bigger family size.

This implies that the more members the family has, the lesser their concern for education and health. Thus, they need to be re-examined not only on the part of the government but also on the vendors to encourage them to put equal importance to their state of health and education (Kolm \& Larsen, 2016; Bernardino \& Andrade, 2014).

When grouped according to the number of years as vendors, data revealed a "low" rating for vendors with 27 years of selling $(M=2.04, S D=1.049)$ while vendors with more than 27 years of experience gave a "very low" rating $(M=1.77, S D=0.841)$. These data suggest that the shorter group had poor access to social services. In contrast, the longer group had very poor access to such services. This downtrend vis-à-vis the longer period may show that the longer the vendors stay in their business, the higher is the possibility that their health and education may deteriorate (Bernardino \& Andrade, 2014).

As to their types of goods, the extent of social implications shows "low" ratings for all types except for Type $C$, which received a "very low" rating $(M=1.41, S D=0.796)$. The findings imply that health and education may improve should the earnings of these vendors also improve. There is a direct proportional measurement between earnings and health/education (Almendral, 2014).

Table 3. Extent of social implications of the relocation of the street vendors

\begin{tabular}{|c|c|c|c|c|c|c|c|c|c|}
\hline \multirow{2}{*}{ Variable } & \multicolumn{3}{|c|}{ Education } & \multicolumn{3}{|c|}{ Health } & \multicolumn{3}{|c|}{ Average } \\
\hline & $\mathbf{M}$ & SD & Int & M & SD & Int & M & SD & Int \\
\hline \multicolumn{10}{|l|}{ Age } \\
\hline Younger & 2.00 & 1.00 & Lo & 1.79 & 0.92 & VL & 1.89 & 0.96 & Lo \\
\hline Older & 2.01 & 1.00 & Lo & 1.80 & 0.90 & VL & 1.91 & 0.95 & Lo \\
\hline \multicolumn{10}{|l|}{ Educational Attainment } \\
\hline Elementary & 1.96 & 0.93 & Lo & 1.98 & 0.90 & Lo & 1.97 & 0.91 & Lo \\
\hline High School & 1.81 & 0.94 & Lo & 1.81 & 0.94 & Lo & 1.81 & 0.94 & Lo \\
\hline College & 1.94 & 1.00 & Lo & 1.94 & 1.00 & Lo & 1.94 & 1.00 & Lo \\
\hline ALS/Voc & 3.30 & 0.99 & Mo & 3.30 & 0.99 & Mo & 3.30 & 0.99 & Mo \\
\hline \multicolumn{10}{|l|}{ Family Size } \\
\hline Few & 1.95 & 0.98 & Lo & 1.95 & 0.98 & Lo & 1.95 & 0.98 & Lo \\
\hline Many & 1.79 & 0.92 & VL & 1.80 & 0.89 & VL & 1.80 & 0.90 & VL \\
\hline \multicolumn{10}{|l|}{ Years of Vending } \\
\hline Shorter & 2.04 & 1.05 & Lo & 2.04 & 1.05 & Lo & 2.04 & 1.05 & Lo \\
\hline Longer & 1.76 & 0.85 & VL & 1.77 & 0.83 & $\mathrm{VL}$ & 1.77 & 0.84 & VL \\
\hline \multicolumn{10}{|l|}{ Type of Goods/Merchandise } \\
\hline Type A (Dry Goods) & 1.94 & 0.88 & Lo & 1.95 & 0.86 & Lo & 1.94 & 0.87 & Lo \\
\hline Type B (Groceries) & 2.52 & 1.02 & Lo & 2.52 & 1.02 & Lo & 2.52 & 1.02 & Lo \\
\hline Type C (Vegetables / Fruits) & 1.41 & 0.80 & VL & 1.41 & 0.80 & VL & 1.41 & 0.80 & VL \\
\hline Type D (Food) & 2.00 & 1.10 & Lo & 2.00 & 1.10 & Lo & 2.00 & 1.10 & Lo \\
\hline As a Whole & 1.91 & 0.95 & Lo & 1.99 & 1.06 & Lo & 1.95 & 1.00 & Lo \\
\hline
\end{tabular}

Note: $\mathrm{VL}=$ Very Low, Lo=Low, Mo=Moderate, $\mathrm{Hi}=$ High 


\section{Differences in the extent of economic implications}

As shown in Table 4, there were significant differences in the vendors' average monthly sales $[t(195)=2.397, p=0.017]$ and average monthly expenses [ $t(195)=2.411, p=0.017]$. However, no significant difference was found in their average monthly income $[t(195)=1.438, p=0.152]$.

Although their relocation has affected their sales and expenses, inherent Filipino values like resiliency and perseverance enable them to rise above their circumstances. According to Sekar (2010), the vendors' positive attitude provides considerable encouragement to the government to seriously improve their conditions.

When the vendors were grouped by family size, there were no significant differences in their vendors' average monthly sales $[t(195)=-0.998, p=0.319]$, average monthly expenses $[t(195)=$ $-0.645, p=0.120]$, and average monthly income $[t(195)=-1.330, p=0.185]$.

Non-monetized factors in terms of family bonding indicated their capacity to provide for the needs of the family. Thus, income takes a significant difference, as previously discussed (Sekar, 2010).

In terms of the number of years as vendors, there were no significant differences in their average monthly sales $[t(195)=1.918, p=0.057]$, average monthly expenses $[t(195)=1.802, p=0.073]$, and average monthly income $[t(195)=0.917, p=0.360]$.

This income factor exists whether they were vending in the downtown area or even while relocating at the Vendors' Plaza. Hence, the number of years spent vending is not a guarantee of improvement in their economic condition (Njaya, 2014).

Table 4. Difference in the extent of economic implications by age, family size, and years of vending

\begin{tabular}{|c|c|c|c|c|c|c|c|c|c|c|}
\hline \multirow{2}{*}{ Variable } & \multirow{2}{*}{ df } & \multicolumn{3}{|c|}{ Monthly Sales } & \multicolumn{3}{|c|}{ Monthly Expenses } & \multicolumn{3}{|c|}{ Monthly Income } \\
\hline & & $\mathbf{M}$ & $\mathbf{t}$ & $\mathbf{p}$ & $\mathbf{M}$ & $\mathbf{t}$ & $\mathbf{p}$ & M & $\mathbf{t}$ & $\mathbf{p}$ \\
\hline \multicolumn{11}{|l|}{ Age } \\
\hline Younger & \multirow{3}{*}{195} & 1.99 & \multirow{3}{*}{$2.397^{*}$} & \multirow{3}{*}{0.017} & 2.18 & \multirow{3}{*}{$2.411^{*}$} & \multirow{3}{*}{0.017} & 1.93 & \multirow{3}{*}{1.438} & \multirow{3}{*}{0.152} \\
\hline \multirow{2}{*}{ Older } & & $\begin{array}{c}(1.17) \\
1.63\end{array}$ & & & $\begin{array}{c}(1.12) \\
1.82\end{array}$ & & & $\begin{array}{c}(1.20) \\
1.71\end{array}$ & & \\
\hline & & $(0.89)$ & & & $(0.98)$ & & & $(1.01)$ & & \\
\hline \multicolumn{11}{|l|}{ Family Size } \\
\hline Few & \multirow{4}{*}{195} & 1.75 & \multirow{4}{*}{0.998} & \multirow{4}{*}{0.319} & 1.96 & & & 1.74 & & \\
\hline \multirow{3}{*}{ Many } & & (1.01) & & & $(1.06)$ & \multirow[t]{3}{*}{0.645} & \multirow[t]{3}{*}{0.120} & (1.04) & \multirow[t]{3}{*}{1.330} & \multirow[t]{3}{*}{0.185} \\
\hline & & 1.91 & & & 2.06 & & & 1.96 & & \\
\hline & & $(1.12)$ & & & $(1.07)$ & & & $(1.22)$ & & \\
\hline \multicolumn{11}{|c|}{ Years of Vending } \\
\hline Shorter & \multirow{4}{*}{195} & 1.95 & \multirow{4}{*}{1.918} & \multirow{4}{*}{0.057} & 2.13 & \multirow{4}{*}{1.802} & \multirow{4}{*}{0.073} & 1.89 & \multirow{4}{*}{0.917} & \multirow{4}{*}{0.360} \\
\hline \multirow{3}{*}{ Longer } & & (1.11) & & & $(1.12)$ & & & $(1.15)$ & & \\
\hline & & 1.68 & & & 1.86 & & & 1.75 & & \\
\hline & & $(0.97)$ & & & (0.99) & & & $(1.07)$ & & \\
\hline
\end{tabular}

Note: *The difference is significant at $p<0.05$.

As shown in Table 5, there were no significant differences in the vendors' average monthly expenses $[F(3,193)=0.902, p=0.441]$ and their average monthly income $[F(3,193)=1.941, p=$ $0.124]$. However, there was a significant difference in their average monthly sales $[F(3,193)=2.792$, $p=0.042]$. Specifically, the group that created the difference were graduates of vocational courses and ALS graduates. Their paired $p$-values were all less than $5 \%$ compared with other educational attainment categories. 
Again, vendors who have attained vocational schooling (VS) or the Alternative Learning System (ALS) appear more adaptable to hard-life. In this regard, the government may create programs that can further ignite the vendors' entrepreneurial initiatives (Khairuzzaman et al., 2014; Kolm \& Larsen, 2016).

When the vendors were grouped by their types of merchandise, results showed that there were significant differences in their average monthly expenses $[F(3,193)=9.335, p=0.000]$, average monthly income $[F(3,193)=14.153, p=0.000]$, and average monthly sales $[F(3,193)=11.029, p=0.000]$.

In terms of average monthly sales, the group that created the difference was the vendors selling Type $C$ goods/merchandise. In terms of monthly expenses, the vendors selling vegetables/fruits are susceptible to very low sales and, consequentially, very low income. The expense may also be very low. This may be proportionate to the calculated decreased sales that the vendors would expect to generate.

Table 5. Difference in the extent of economic implications by educational attainment, and type of goods/merchandize

\begin{tabular}{|c|c|c|c|c|c|c|c|c|c|c|}
\hline \multirow{2}{*}{ Variable } & \multirow{2}{*}{ df } & \multicolumn{3}{|c|}{ Monthly Sales } & \multicolumn{3}{|c|}{ Monthly Expenses } & \multicolumn{3}{|c|}{ Monthly Income } \\
\hline & & M & $\mathbf{F}$ & $\mathbf{p}$ & M & $\mathbf{F}$ & $\mathbf{p}$ & M & $\mathbf{F}$ & $\mathbf{p}$ \\
\hline \multicolumn{11}{|c|}{ Educational Attainment } \\
\hline \multirow[t]{2}{*}{ Elementary } & & 1.82 & & & 2.02 & & & 1.87 & & \\
\hline & & $(1.11)$ & & & $(1.02)$ & & & (1.19) & & \\
\hline \multirow[t]{2}{*}{ H. School } & & 1.77 & & & 1.97 & & & 1.74 & & \\
\hline & & $(1.00)$ & & & (1.09) & & & $(1.04)$ & & \\
\hline \multirow[t]{2}{*}{ College } & 3,193 & 1.78 & 2.792 & 0.042 & 1.95 & 0.902 & 0.441 & 1.84 & 1.941 & 0.124 \\
\hline & & $(1.09)$ & & & (1.03) & & & $(1.09)$ & & \\
\hline \multirow[t]{2}{*}{ ALS/Voc } & & 3.90 & & & 3.20 & & & 3.60 & & \\
\hline & & $(1.56)$ & & & $(1.98)$ & & & (1.98) & & \\
\hline \multicolumn{11}{|c|}{ Type of Goods/Merchandise } \\
\hline \multirow[t]{2}{*}{ Type A } & & 1.80 & & & $2.08 \mathrm{~b}$ & & & 1.73 & & \\
\hline & & $(0.98)$ & & & $(1.02)$ & & & $(0.98)$ & & \\
\hline \multirow[t]{2}{*}{ Type B } & & 2.34 & & & 2.52 & & & $2.63 c$ & & \\
\hline & & $(1.04)$ & & & $(0.89)$ & & & (1.10) & & \\
\hline \multirow[t]{2}{*}{ Type C } & 3,193 & 1.30 & 9.335 & 0.000 & 1.28 & 14.153 & 0.000 & 1.33 & 11.029 & 0.000 \\
\hline & & $(0.81)$ & & & $(0.69)$ & & & $(0.89)$ & & \\
\hline \multirow[t]{2}{*}{ Type D } & & 2.41 & & & 2.61 & & & 2.33 & & \\
\hline & & (1.36) & & & (1.39) & & & (1.50) & & \\
\hline
\end{tabular}

Note: ${ }^{*}$ The difference is significant at $p \leq 0.05$.

\section{Differences in the extent of social implications}

As shown in Table 6, there were no significant differences in the vendors' education $[t(195)=$ $1.611, p=0.109]$ and the vendors' health $[t(195)=1.550, p=0.123]$.

The vendors' conditions regarding their health and education did not change despite their relocation to the new site. As a characteristic of their livelihood, meeting daily needs puts primary importance over their health (Golosino, 2012; Bernardino \& Andrade, 2014).

When grouped by their number of dependent family members, the extent of social implications showed no significant differences in their education $[t(195)=1.153, p=0.250]$ and health $[t(195)=$ $1.058, p=0.291]$. The vendors' concerns regarding their children's education are their security and safety and the distance of the schools to their vending area. These inadequacies are also present even while they were in the downtown area (Bernardino \& Andrade, 2014; Walsh, 2010). 
However, when the vendors were grouped by their number of years as vendors, there were significant differences on their education $[t(195)=2.205, \mathrm{p}=0.042]$ and health $[t(195)=1.993, \mathrm{p}$ $=0.048]$.

This implies that the longer the vendors are in their stagnant conditions, their health and education further deteriorate; thus, no significant differences exist between their education and health.

Table 6. Difference in the extent of social implications by age, family size, and years of vending

\begin{tabular}{|c|c|c|c|c|c|c|c|}
\hline \multirow{2}{*}{ Variable } & \multirow{2}{*}{ df } & \multicolumn{3}{|c|}{ Education } & \multicolumn{3}{|c|}{ Health } \\
\hline & & M & $\mathbf{t}$ & $\mathbf{p}$ & M & $\mathbf{t}$ & $\mathbf{p}$ \\
\hline \multicolumn{8}{|l|}{ Age } \\
\hline Younger & \multirow{4}{*}{195} & 2.01 & \multirow{4}{*}{1.611} & \multirow{4}{*}{0.109} & 2.01 & \multirow{4}{*}{1.550} & \multirow{4}{*}{0.123} \\
\hline \multirow{3}{*}{ Older } & & $(1.00)$ & & & $(1.00)$ & & \\
\hline & & 1.79 & & & 1.8 & & \\
\hline & & $(0.92)$ & & & $(0.90)$ & & \\
\hline \multicolumn{8}{|l|}{ Family Size } \\
\hline Few & \multirow{4}{*}{195} & 1.95 & \multirow{4}{*}{1.153} & \multirow{4}{*}{0.250} & 1.95 & \multirow{4}{*}{1.058} & \multirow{4}{*}{0.291} \\
\hline \multirow{3}{*}{ Many } & & $(0.98)$ & & & $(0.98)$ & & \\
\hline & & 1.79 & & & 1.8 & & \\
\hline & & $(0.92)$ & & & $(0.89)$ & & \\
\hline \multicolumn{8}{|c|}{ Years of Vending } \\
\hline Shorter & \multirow{4}{*}{195} & 2.04 & \multirow{4}{*}{$2.205^{*}$} & \multirow{4}{*}{0.042} & 2.04 & \multirow{4}{*}{$1.993^{*}$} & \multirow{4}{*}{0.048} \\
\hline \multirow{3}{*}{ Longer } & & $(1.05)$ & & & (1.05) & & \\
\hline & & 1.76 & & & 1.77 & & \\
\hline & & $(0.85)$ & & & $(0.83)$ & & \\
\hline
\end{tabular}

Note: *The difference is significant at $\mathrm{p} \leq 0.05$.

Moreover, in terms of their educational attainment, the extent of social implications showed no significant differences in their education $[F(3,193)=1.855, \mathrm{p}=0.139]$ and their health $[F(3,193)$ $=1.942, p=0.124]$. These results reflect that education and health did not significantly provide the vendors with the changes for improvement; thus, the vendors' status on health and education further deteriorates in the passing of years (Bernardino \& Andrade, 2014; Walsh, 2010).

Conversely, when grouped by their types of merchandise, the findings revealed no significant differences in the vendors' education $[F(3,193)=9.429, p=0.000]$ and their health $[F(3,193)=$ 9.643, $p=0.000]$. 
Table 7. Difference in the extent of social implications by educational attainment, and type of goods

\begin{tabular}{|c|c|c|c|c|c|c|c|}
\hline \multirow{2}{*}{ Variable } & \multirow{2}{*}{ df } & \multicolumn{3}{|c|}{ Education } & \multicolumn{3}{|c|}{ Health } \\
\hline & & $\mathbf{M}$ & $\mathbf{F}$ & $\mathbf{p}$ & $\mathbf{M}$ & $\mathbf{F}$ & $\mathbf{p}$ \\
\hline \multicolumn{8}{|c|}{ Educational Attainment } \\
\hline \multirow[t]{2}{*}{ Elementary } & & 1.96 & & & 1.98 & & \\
\hline & & $(0.93)$ & & & $(0.90)$ & & \\
\hline \multirow[t]{2}{*}{ High School } & & 1.81 & & & 1.81 & & \\
\hline & 3,193 & & 1.855 & 0.139 & & 1.942 & 0.124 \\
\hline \multirow[t]{2}{*}{ College } & & 1.94 & & & 1.94 & & \\
\hline & & $(1.00)$ & & & $(1.00)$ & & \\
\hline \multirow[t]{2}{*}{ ALS/Voc } & & 3.30 & & & 3.30 & & \\
\hline & & $(0.99)$ & & & $(0.99)$ & & \\
\hline \multicolumn{8}{|c|}{ Vendor's Type of Goods/Merchandise } \\
\hline \multirow[t]{2}{*}{ Type A } & & 1.94 & & & 1.95 & & \\
\hline & & $(0.88)$ & & & $(0.86)$ & & \\
\hline \multirow[t]{2}{*}{ Type B } & & 2.52 & & & 2.52 & & \\
\hline & 3,193 & $(1.02)$ & $9.249 *$ & 0.000 & $(1.02)$ & $9.643^{*}$ & 0.000 \\
\hline \multirow[t]{2}{*}{ Type C } & & 1.41 & & & 1.41 & & \\
\hline & & $(0.80)$ & & & $(0.80)$ & & \\
\hline \multirow[t]{2}{*}{ Type D } & & 2.00 & & & 2.00 & & \\
\hline & & (1.10) & & & (1.10) & & \\
\hline
\end{tabular}

Note: ${ }^{*}$ The difference is significant at $p \leq 0.05$.

\section{Challenges encountered by displaced vendors}

As shown in Table 8, findings revealed four major challenges among the relocated vendors, ranked in the seriousness of their concerns, which are as follows: (1) Their means of livelihood is very difficult ( $p=83.8 \%$ ); (2) There was not enough financial support given during their relocation ( $p$ $=56.3 \%) ;(3)$ They have limited space/trading site ( $p=52.8 \%)$; and (4) There is the lack of access to credit facility $(p=52.8 \%)$.

Previous studies with similar findings reinforce these results. The vendors consider vending to be a very difficult means of livelihood (Golosino, 2012); meager financial support during relocation (Recio \& Gomez, Jr., 2013); limited selling space (Dunn, 2014) and the lack of access to the credit facility (Walsh, 2014).

Dislocation, followed by relocation, needs many adjustments to the vendors (Sujatha, 2016). They have to face some expenditures in their transfer, putting pressure on their financial resources (Panwar, 2015). The government cannot immediately provide these financial requirements of the vendors due to public bureaucracy, especially on the use of public funds (Kumari, 2016; Kasmad \& Alwi, 2015).

In synthesis, the findings of the study revealed that even though vendors were relocated to the new site, such relocation has not made a difference in their lives. Likewise, they encountered worse conditions in terms of their health and education.

In this context, the study has shown that peddling in public places has been long tolerated and allowed to flourish in the city for decades until MC No. 2019-121 came into play, abruptly relocating the vendors without appropriate preparations. Although vending in public places is a nuisance and is a clear violation of the law, the government's willing tolerance for a long time has made the vendors 
believe that the law is toothless or impotent, thereby giving the impression of weak governance. The challenge is about finding a balance between the government and the governed.

Table 8. Challenges encountered by displaced street vendors

\begin{tabular}{lccc}
\hline Challenges & $\mathrm{f}$ & $\%$ & Rank \\
\hline Means of livelihood is very difficult. & 165 & 83.8 & 1 \\
Not enough financial support is given during the relocation. & 111 & 56.3 & 2 \\
Many vendors have limited space/ trading sites. & 104 & 52.8 & 3.5 \\
Lack of access to the credit facility. & 104 & 52.8 & 3.5 \\
Problems with site allocation systems. & 88 & 44.7 & 5 \\
No enough supply of water. & 82 & 41.6 & 6 \\
Accessibility to various government facilities is very difficult. & 69 & 35.0 & 7 \\
The general transport vehicle is scarce. & 50 & 25.4 & 8 \\
The provision for electric power is not given. & 49 & 24.9 & 10 \\
Waste Disposal and Sanitation Facility are not provided in the relocation site. & 49 & 24.9 & 10 \\
Police visibility and other safety and security measures are not provided. & 39 & 19.8 & 11 \\
Organizational leadership in the area is not formed. & 38 & 19.3 & 12 \\
Harassment by the police and other relocation implementing agencies occurs. & 36 & 18.3 & 13 \\
The food market is not available or is far from the relocation site. & 35 & 17.8 & 14 \\
Access to churches is not provided and is far from the relocation site. & 25 & 12.7 & 15
\end{tabular}

\subsection{Conclusion}

The vendors' economic and social conditions did not change despite their relocation to the Vendors' Plaza. The sudden implementation of DILG MC No. 2019-121 by the local government triggering the vendors' immediate relocation would have worsened their business situations. However, it becomes an opportunity for the government to identify and address these major difficulties experienced by the vendors.

Nevertheless, the study also revealed that despite the vendors' hardship in the relocation, they remain optimistic in their social and economic challenges.

This gives an opportune time for the government to take a panoramic view that vendors are not what they are perceived to be; rather, they can be potential engines of growth to uplift living conditions, a regular source of income and self-independence, providers of jobs, boosters of entrepreneurial activities, and relievers of poverty and unemployment.

It is recommended that market ordinances be reviewed for amendments. Modern laws like the Private-Public Partnership are used in developing the Vendors' Plaza and other structures, and that assistance is provided to the vendors to form one solid mother-organization as well as to establish their cooperative.

\section{REFERENCES}

Almendral, A. (2014). Street vendors have a lot to teach us about urban space works. Retrieved from https://nextcity.org/daily/entry/ street-vendors-have-a-lot-to-teach-us-about-how-urban-space-works.

An Act Providing for a Local Government Code of 1991 (Phi.). Retrieved from https://www.officialgazette.gov.ph/1991/10/10/republicact-no-7160/

Bernardino, D. \& Andrade, M. (2014). "The health condition of women working as street vendors: an observational study." Retrieved from http://www.objnursing.uff.br/index.php/nursing/article/view/5027/html_259

Bhowmik, S. (2003). Urban Responses to Street Trading: India. Retrieved from http://www.wiego.org/sites/default/files/publications/ files/Bhowmik_Urban_Responses_to_Street_Trading_India.pdf

Bhowmik, S. (2005). Street Vendors in Asia: A Review. Retrieved from https://www.wiego.org/sites/default/files/publications/files/ Bhowmik-Street-Vendors-Asia.pdf

Department of Interior and Local Government (2019) https://www.dilg.gov.ph/PDF_File/issuances/memo_circulars/dilg-memocircular2019729_2c2087a765.pdf 
Dhungel, K. R. \& Dhungel, N.K. (2011). Impact of the current financial crisis on the employment of street vendors in the urban centers of Kathmandu Valley (SANEI Working Paper Series No. 11-09). South Asia Network of Economic Research Institutes, March 2011, Bangladesh Institute of Development Studies (BIDS), E-17, Agargaon, Sher-E-Bangla Nagar, GPO Box \# 3854 , Dhaka-1207, Bangladesh.

Dixon (2013). Dixon - Critical Theory: Street vending. Retrieved on December 13, 2019, from uicsocialtheory.weebly.com/criticaltheory/dixon-critical-theory-street-vending.

Forkuor, J., Akuoko, K. \& Yeboah, E. (2017). Negotiation and management strategies of street vendors in developing countries: $A$ narrative review. SAGE Open. 7. 215824401769156. 10.1177/2158244017691563.

Gervasi, M. (2010). Surakarta, Indonesia: Empowering the Informal sector: Street vendor management. Retrieved on November 18, 2019, from https://www.uclg.cisdp.org/sites/default/files/Surakarta_2010_en_final.pdf

Ghani, A. (2011). A recipe for success: How Singapore Hawker Centers came to be. Retrieved from https://lkyspp.nus.edu.sg/docs/ default-source/ips/ag_history-of-hawkers_010511.pdf

Golosino, E. (2012). The Unheard Stories of the Sidewalk Vendors of Tagbilaran City, Bohol, Philippines. Retrieved from https:// ejournals.ph/article.php?id=571

Graaff, K. \& Ha, N. (eds). 2015. Street vending in the neoliberal city: A global perspective on the practices and policies of a marginalized economy. New York and Oxford: Berghahn Books. Retrieved from https://www. berghahnbooks. com/downloads/intros/ GraaffStreet_intro.pdf

Indira, D. (2014). A study of street vending across the globe. International Journal of Advanced Research in Computer Science and Software Engineering, Vol 4, Is 9 . Retrieved on November 20, 2019, from www.ijarcsse.com.

Kasmad, R. \& Alwi, H. (2015). Dilemma of Values in public policy accountability: Implementation of the street vendors' empowerment policy network in Makassar City. Retrieved from https://www.researchgate.net/publication/283239053_Democratic_Model_of_ Public_Policy_Accountability_Case_Study_on_Implementation_of_Street_Vendors_Empowerment_Policy_in_Makassar_City

Khairuzzaman, M., Chowdhury, F., Zaman, S., Mamun, A., \& Bari, L. (2014). Food safety challenges towards safe, healthy, and nutritious street foods in Bangladesh. International Journal of Food Science, Volume 2014, Article ID 483519, 9 pages http://dx.doi. org/10.1155/2014/483519

Kolm, A. \& Larsen, B. (2016). Informal unemployment and education. IZA J Labor Econ 5, 8 (2016). doi:10.1186/s40172-016-0048-6

Kumah, C. (2015). A comparative study of the use of the library and the internet as sources of information by graduate students in the University of Ghana. Retrieved from https://digitalcommons.unl.edu/cgi/viewcontent.cgi?article=3473\&context=lib philprac

Kumari, Pinki. (2016). Issues and challenges for street vendors in Delhi. Retrieved on December 17, 2019, from papers.ssm.com/sol3/ papers.cfm?abstract_id $=2779343$

Myrdal, G. (1975). The equality issue in world development. Retrieved from https://www.nobelprize.org/prizes/economicsciences/1974/myrdal/lecture/

Njaya, T. (2014). Employment creation or sheer survival? Case of street vendors of Harare Metropolitan in Zimbabwe. Global Journal of Advanced Research, 1(2). pp. 264 - 274.

Panwar, Ar. Manoj (2015). Issues and challenges faced by vendors on urban streets: A Case of Sonipat City, India. Retrieved on December 17, 2019, from researchgate.net/publication/280310189_ISSUES_AND_CHALLENGES_FACED_BY_VENDORS_ON_ URBAN_STREETS_A_CASE_OF_SONIPAT_CITY_INDIA

Purnomo, R. (2017). Economic impact analysis of relocation five feet vendors in Purwokerto. JEJAK: Jurnal Ekonomi Dan Kebijakan, 10(2), 242-256. doi:http://dx.doi.org/10.15294/jejak.v10i2.11291

Recio, R. \& José Jr., J.E.A. (2013). Street vendors, their contested spaces, and the policy environment: A view from Caloócan, Metro Manila. Environment and Urbanization Asia. 4. 173-190. 10.1177/0975425313477760.

Sangguniang Panlungsod, Bacolod City, http://www.bacolodcity.gov.ph/

Sekar, H. R. (2010). Insecurities and vulnerabilities of informal sector vendors with a special focus on the street vending children of Noida. Retrieved from https://www.researchgate.net/publication/290559310_Exploring_the_Socio-economic_Life_of_Sidewalk_ Vendors.

Singh, A. \& Kumar, S. (2017). Trade Unions in Transformation towards a Better Deal for Street Vendors in India: The Case of NASVI. Retrieved from https://library.fes.de/pdf-files/iez/13641.pdf

Taylor, J. (2016). Making public markets work: Street food vendor relocation in two Indonesian cities. Urban Agriculture Magazine, Number 31, September 2016. E-mail: indojota@gmail.com. (www.ruaf.org.)

Walsh, J. (2010). Street vendors and the dynamics of the informal economy: Evidence from Vung Tau, Vietnam. Asian Social Science, Volume 6, Number 11, November 2010

\section{Correspondence:}

JOSELITO T. BAYATAN

integritas91@gmail.com

https://orcid.org/0000-0002-9570-2974

ANABELLE S. PALIC

aspalic@yahoo.com 